\title{
Thermal Stability of DNA: DNA Hybrids within the Genus Agrobacterium
}

\author{
By J. DE LEY, R. TIJTGAT, J. DE SMEDT AND M. MICHIELS \\ Laboratory of Microbiology and Microbial Genetics, Faculty of Sciences, \\ State University, K.L. Ledeganckstraat 35, 9000 Gent, Belgium
}

(Received 29 January I973; revised I I April 1973)

\section{SUMMAR Y}

Molecular hybrids were prepared between unlabelled DNA from representative strains of eleven genetic races of Agrobacterium and $\left[{ }^{14} \mathrm{C}\right] \mathrm{DNA}$ from typical strains of each of the three main races. The thermal stability of each hybrid was determined. The nature of the hybrids formed varied with the incubation temperature and the kind of DNA used. Hybridization in $2 \times$ SSC $-30 \%$ dimethylsulphoxide below $59{ }^{\circ} \mathrm{C}$ yielded two kinds of hybrids: a labile one of unknown nature, denaturing below $59{ }^{\circ} \mathrm{C}$, and a more or less stable hybrid denaturing above that temperature. The latter was the only one formed in hybridizations at or above $59{ }^{\circ} \mathrm{C}$. There were three kinds of stable hybrids. Within each of the main Agrobacterium races thermal stability of the molecular hybrid was about the same (within $2{ }^{\circ} \mathrm{C}$ ) as for the homoduplex. Between two races of $50 \%$ DNA relatedness, the duplexes were about $6{ }^{\circ} \mathrm{C}$ less stable. Between races of Io to $15 \%$ DNA relatedness, the duplexes were weak, and the stability was at least $13{ }^{\circ} \mathrm{C}$ lower. The stability of the hybrids decreased concomitantly with the degree of DNA relatedness. The decreased hybrid denaturation curve is not due to AT-rich sequences. The less two races of agrobacteria appeared to be evolutionarily related, the more mutations occurred within the common part.

\section{INTRODUCTION}

From previous studies it appeared that the genus Agrobacterium is genetically very heterogeneous. DNA of cluster I (typical Agrobacterium tumefaciens and A. radiobacter strains), cluster 2 ( $A$. rhizogenes and atypical $A$. tumefaciens strains), the 'rubi' group and two very small groups hybridize at about 10 to $15 \%$. Within cluster I the DNA of the seven groups hybridize at about $50 \%$ and within each group at least $80 \%$ (De Ley, I972; Kersters, De Ley, Sneath \& Sackin, I973; J. De Ley, A. Reynaerts \& H. Cattoir, unpublished).

Mutational events modified considerable parts of the genomes, preventing in vitro molecular hybridization. Considering the evolutionary history of a bacterial genus, one can wonder whether mutations also occurred within the common DNA parts. For an experimental answer to that question we prepared a number of DNA-hybrids between the genomes of different Agrobacterium groups and clusters, and determined their thermal stability which is interpreted as a measure of base-pairing imperfections, and mutational differences (Brenner \& Cowie, 1967). We established that decreased hybrid denaturation curves were not due to preferential binding of heterologous AT-rich DNA sequences. 


\section{METHODS}

Bacteria. The strains used are listed in Table I; many of them are briefly described elsewhere (Kersters et al. 1973). As controls we included Salmonella typhimurium $\mathrm{r}$ and Acetobacter aceti Ch 3I, which have a very low relationship with the agrobacteria (J. De Smedt \& J. De Ley, unpublished).

The agrobacteria were grown on a medium of $(\mathrm{g} / \mathrm{l})$ : yeast extract paste, I0; glucose, Io; $\left(\mathrm{NH}_{4}\right)_{2} \mathrm{SO}_{4}, \mathrm{I}$; and $\mathrm{KH}_{2} \mathrm{PO}_{4}, 0 \cdot 25$. Salmonella were grown on beef extract (Oxoid), I0; peptone, I0; and $\mathrm{NaCl}, 5$. Acetobacters were grown on yeast extract paste, I0; glucose, 50; and $\mathrm{CaCO}_{3}, 30$. All media were made with $2.5 \%$ agar in tap water. All bacteria were grown at 28 to $30^{\circ} \mathrm{C}$ for 2 to 3 days, harvested and washed.

DNA preparation. DNA from all strains was extracted and purified as described by De Ley, Cattoir \& Reynaerts (I970).

${ }^{14}$ C-Labelled DNA from the reference strains Agrobacterium tumefaciens B6, TTII I and B2a, and $A$. rhizogenes TR7 were prepared as described previously (De Ley, Bernaerts, Rassel \& Guilmot, I966; Heberlein, De Ley \& Tijtgat, I967) with Marmur's ( I96I) method, supplemented by a pronase treatment of $40 \mu \mathrm{g} / \mathrm{ml}$ at $37^{\circ} \mathrm{C}$ for about $15 \mathrm{~h}$. The specific activity was $3700,4000,3600$ and 5500 d.p.m./ $\mu$ g respectively.

Purified native DNA for fixation on a filter had a molecular weight of 5 to $10 \times 10^{6}$. Labelled DNA for hybridization was sheared to a molecular weight of $4 \times 10^{5}$ by passage through a French pressure cell at $2 \mathrm{I} 000 \mathrm{lb} / \mathrm{in}^{2}$.

Fixation of denatured, high molecular weight DNA on membrane filters. This was carried out as described previously (De Ley \& Tijtgat, I970). PHWP Millipore filters were used, diam. 47 or $90 \mathrm{~mm}$. Smaller filters of diam. $9 \mathrm{~mm}$ were punched out of them after fixation of the DNA, each containing usually 20 to $22 \mu \mathrm{g}$ of DNA.

DNA: DNA hybridization. We used the method of Legault-Démare, Desseaux, Heyman, Séror \& Ress (1967), in the conditions recommended by De Ley \& Tijtgat (1970). The final volume was $0.8 \mathrm{ml} 2 \times$ SSC-DMSO, containing $3 \mu \mathrm{g}$ of sheared, denatured, ${ }^{14} \mathrm{C}$-labelled reference DNA and a $9 \mathrm{~mm}$ DNA-loaded filter. The optimal renaturation temperature of $59^{\circ} \mathrm{C}$ was commonly used, although $42{ }^{\circ} \mathrm{C}, 62{ }^{\circ} \mathrm{C}$ and $72{ }^{\circ} \mathrm{C}$ were used occasionally. SSC buffer contained $0.15 \mathrm{M}-\mathrm{NaCl}$ in $0.015 \mathrm{M}$-sodium citrate, $\mathrm{pH} 7.0 ; 2 \times \mathrm{SSC}$-DMSO contains $2 \times \mathrm{SSC}$ solution in a mixture of $70 \%$ water and $30 \%$ dimethylsulphoxide.

Determination of thermal stability of DNA: DNA hybrids. After hybridization the filters were removed and washed in $2 \times$ SSC-DMSO. They were incubated for $15 \mathrm{~min}$ in each one of a series of small flasks, containing $2 \mathrm{ml}$ of $2 \times$ SSC-DMSO, in a series of water baths of increasing temperatures in $3{ }^{\circ} \mathrm{C}$ steps from the hybridization temperature up to $89{ }^{\circ} \mathrm{C}$. No residual counts remained on the filters at $89{ }^{\circ} \mathrm{C}$. The amount of labelled DNA removed was counted in a Tricarb 3310 Liquid Scintillation Spectrometer, by adding $0.5 \mathrm{ml}$ portions of the washings to $19.5 \mathrm{ml}$ of Bray ( 1960 ) solution, cooled to $2{ }^{\circ} \mathrm{C}$ for several hours and counted repeatedly for 20 to $50 \mathrm{~min}$. $T_{m(e)}$ is the thermal elution midpoint, the temperature at which $50 \%$ of the DNA bound (at the $59{ }^{\circ} \mathrm{C}$ hybridization temperature) is eluted.

\section{RESULTS}

\section{Kinetics of DNA hybridization}

In a previous paper (De Ley \& Tijtgat, I970) we established the optimal conditions for DNA hybridizations on membrane filters. We report here on the different types of Agrobacterium DNA hybrids which are formed as one varies the incubation time and temperature. 

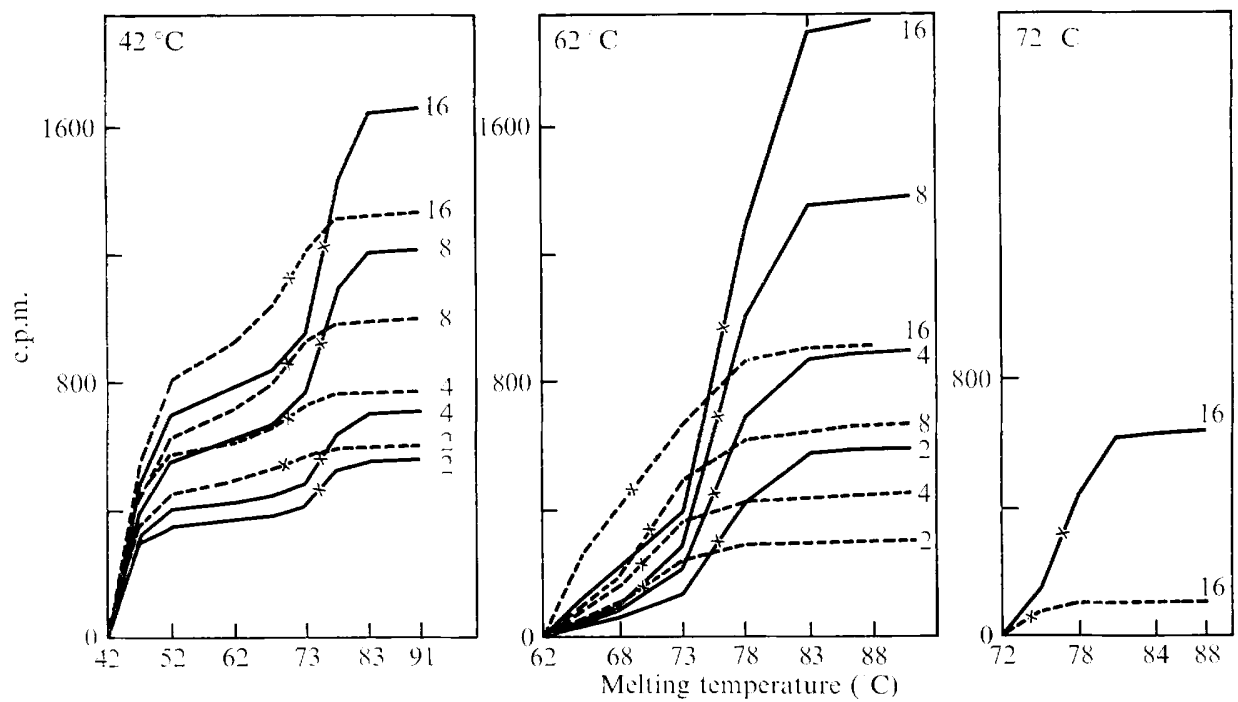

Fig. 1. Kinetics of homologous and heterologous Agrobacterium DNA hybridization. Thermal stability of the hybrids. Sheared, single-stranded [ $\left.{ }^{14} \mathrm{C}\right]$ labelled DNA of Agrobacterium tumefaciens TTI I I was incubated in $2 \times$ SSC-DMSO with filter-fixed ordinary, high-molecular-weight, singlestranded DNA from either strain TTIII or A. tumefaciens B6 at either $42{ }^{\circ} \mathrm{C}, 62{ }^{\circ} \mathrm{C}$ or $72{ }^{\circ} \mathrm{C}$ for several lengths of time as shown on the graphs. The filter was removed and washed. The thermal stability was determined as described under Methods. The crosses $(x)$ are the melting points of elution $T_{m(e)}$. Full lines are melting curves of the homoduplexes $\left[{ }^{14}\right.$ C]TTI I I : TTI I I, broken lines of the heteroduplexes $\left[{ }^{14} \mathrm{C}\right]$ тті I I : $\mathbf{B} 6$. The numbers next to the curves represent the time of hybridization in $\mathrm{h}$. The incubation temperatures are shown in the upper left corners.

As a model system we prepared the homoduplex TTII $:\left[{ }^{14} \mathrm{C}\right]$ TTIII, and the heteroduplex B6: $\left[{ }^{14} \mathrm{C}\right]$ TTI I I in 2 SSC-DMSO at $42{ }^{\circ} \mathrm{C}$ and $62{ }^{\circ} \mathrm{C}$ after $2,4,8$ and $\mathrm{I} 6 \mathrm{~h}$ of incubation, and at $72{ }^{\circ} \mathrm{C}$ after $\mathrm{I} 6 \mathrm{~h}$ of incubation. The thermal stability of all these duplexes was determined. The results are shown in Fig. I.

At $42{ }^{\circ} \mathrm{C}$ two types of duplexes are formed. The first is weakly bound and denatures below $59^{\circ} \mathrm{C}$. We shall call it here the 'labile duplex'. The second type displays a more stable denaturation profile. We shall call it here the 'stable duplex'. The labile duplex is formed much faster than the stable one. About one-half of the amount is formed after $2 \mathrm{~h}$ of incubation. There is more of the labile heteroduplex than of the labile homoduplex under identical conditions. The labile duplex is not formed when the hybridization is carried out at $62{ }^{\circ} \mathrm{C}$, and $a$ fortiori at $72{ }^{\circ} \mathrm{C}$.

The formation of the labile duplex consumes a considerable amount of the available reference $\left[{ }^{14} \mathrm{C}\right] \mathrm{DNA}$. This explains why the amount of stable duplex is about twice as much at $62{ }^{\circ} \mathrm{C}$ as it is at $42{ }^{\circ} \mathrm{C}$. The midpoint of elution, $T_{m(e)}$, of the stable duplex is the same for each type of duplex at both working temperatures: $76^{\circ} \mathrm{C}$ for the stable homoduplex TTI I I : TTI I I and $70{ }^{\circ} \mathrm{C}$ for the stable heteroduplex B6:TTI I I. This difference of $6{ }^{\circ} \mathrm{C}$ between both types of duplexes was an important observation and led to all following experiments.

When hybridization is carried out at $72{ }^{\circ} \mathrm{C}$, only a fraction of the stable duplex is formed: one-third of the homoduplex and only I I \% of the heteroduplex. The $T_{m(e)}$ of the homoduplex is now higher $\left(77^{\circ} \mathrm{C}\right)$ and that of the heteroduplex is $74^{\circ} \mathrm{C}$. 
Table I. $T_{m(e)}$ of the stable duplexes between DNA from a number of Agrobacterium strains with $\left[{ }^{14} C\right] D N A$ from the reference strains $A$. tumefaciens TTII I and $\mathrm{B} 6$ and from $A$. rhizogenes TR7

The results are expressed in ${ }^{\circ} \mathrm{C}$. Abbreviations of strain numbers as in Kersters et al. (1973).

'Low' refers to a weakly stable molecular hybrid with $T_{m(e)} \leqslant 62{ }^{\circ} \mathrm{C}$. The division into clusters and groups was made according to De Ley (1972) and Kersters et al. (1973).

Bacteria

(name as received)

A. tumefaciens

A. radiobacter

A. tumefaciens

A. tumefaciens

A. tumefaciens

A. tumefaciens

A. tumefaciens

A. tumefaciens

Presumed Agrobacterium

A. tumefaciens

A. tumefaciens

A. tumefaciens

A. tumefaciens

A. tumefaciens

A. tumefaciens

A. tumefaciens

A. tumefaciens

A. tumefaciens

A. tumefaciens

A. tumefaciens

A. tumefaciens

A. tumefaciens

A. tumefaciens

A. tumefaciens

A. tumefaciens

A. tumefaciens

A. tumefaciens

A. tumefaciens

A. tumefaciens

A. tumefaciens

A. radiobacter

A. radiobacter

$A$. radiobacter

A. radiobacter

A. tumefaciens

A. tumefaciens

Agrobacterium sp.

A. tumefaciens

A. tumefaciens

A. tumefaciens

A. tumefaciens

A. radiobacter

Agrobacterium sp.

A. tumefaciens

A. tumefaciens

A. tumefaciens

A. tumefaciens

A. tumefaciens

A. tumefaciens

DNA of strain on membrane filter

Reference $\left[{ }^{14} \mathrm{C}\right] \mathrm{DNA}$

$\overbrace{\text { ICPB TTIII }}$ B6

Cluster I

TTI I I group

ICPB TTI I I

NCIB 8149

NCPPB 1001

A6

II CHR

ATB

ATV

Gembloux A

AB 1558

NCPPB 4

NCPPB 5

ATCC 143

ATCC 4720

ICPB TT6

NCPPB 398

NCPPB 396

ICPB TT5

ICPB TT 7

ICPB TT8

NCPPB I 674

IIBV7

Mushin 3

Mushin 5

I 8 I

E.III 9.6. I

IPO 4 I 7

AT3

C1P в6

в6-806

B2a

ICPB TR6

SIOO5

ATCC 47 I 8

ICPB TR I

Delft F

ATCC 4452

Kerr 14

ATCC I I I 56

ATCC 1 I 158

ICPB TT2

ICPB TTI I

ATCC 13332

0322

NIAS 1

NIAS A-2-I - I

H 5

CIP RV3

Zutra 3/1

NCPPB I 64 I
$75 \cdot 4 \pm 0 \cdot 2$
$74 \cdot 3$

$74 \cdot 3$
$72 \cdot 2$

$74 \cdot 1$

73.5

$74^{\circ} \mathrm{O}$

$73 \cdot 4$

$75 \cdot 9$

$74^{\circ} 4$

$75 \cdot 5$

$75^{\circ} 6$

$75 \cdot 7$

$75 \cdot 6$

$75 \cdot 9$

$74 \cdot 6$

75

72

72

$71 \cdot 9$

$74 \cdot 9$

$75^{\circ} 1$

76

75.9

76

$75 \cdot 2$

B6 group

-

69.5

69

$69 \cdot 3$

$68 \cdot 6$

$69 \cdot 1$

$69 \cdot 4$

$69 \cdot 6$

$69 \cdot 9$

$70 \cdot 4$

$70-1$

69.9

$70 \cdot 2$

$68 \cdot 8$

$67 \cdot 1$

$68 \cdot 8$

-

$-$

RV3 group

69.6

66.
$68 \cdot 4$

$68 \cdot 8$

$67 \cdot 9$

68.6

$68 \cdot 4$

$68 \cdot 7$

69.0

$70 \cdot 2$

$69 \cdot 1$

-

70.0

$70 \cdot 0$

-

$69 \cdot 4$

$69 \cdot 4$

$69 \cdot 1$

69

69.4

$69 \cdot 1$

$69 \cdot 9$

$69 \cdot I$

$69 \cdot 2$

$68 \cdot 7$

69.5

$75 \cdot 8$

76

$75 \cdot 6$

$75 \cdot 5$

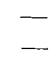

$75 \cdot 1$

$75 \cdot 5$

76

$75 \cdot 5$

$75 \cdot \mathrm{I}$

$75 \cdot 3$

$76 \cdot 3$

$75 \cdot 8$

- low

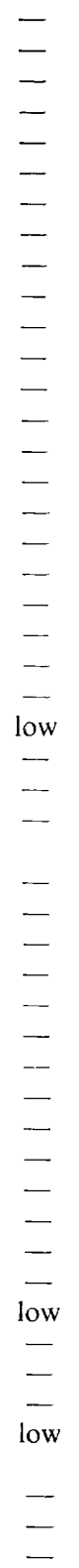


Table I (cont.)

Bacteria

(name as received)

Agrobacterium sp.

Agrobacterium sp.

A. tumefaciens

A. tumefaciens

A. tumefaciens

A. tumefaciens

A. tumefaciens

$A$. radiobacter

A. radiobacter

A. rhizogenes

A. rhizogenes Agrobacterium sp.

Agrobacterium sp.

A. tumefaciens

A. tumefaciens

A. tumefaciens

A. rhizogenes

A. tumefaciens

Agrobacterium sp.

A. tumefaciens

A. rhizogenes

A. tumefaciens

A. tumefaciens

A. tumefaciens

A. tumefaciens

A. tumefaciens

A. tumefaciens

A. tumefaciens

A. tumefaciens

A. rhizogenes

A. rhizogenes

A. rubi

A. rubi

A. tumefaciens

A. tumefaciens

A. tumefaciens

Salmonella typhimurium Acetobacter aceti
DNA of strain on membrane filter

0362

0363

ICPB TT9

T37

Mushin 6

Zutra F/I

NCPPB 925

M 2/1

L $2 / 2 / 1$

ICPB TR7

ICPB TRIOI

Kerr 38

Kerr 39

ICPB TTI 33

NCPPB I 649

NCPPB I65I

ICPB TRIO7

P2

O32I

Apple I 85

NCIB 8196

PPI $49 \mathrm{~b}$

PPI 6

PPI I

NIAS SI

AG 6

AG I

NCPPB 794

NCPPB 223

ATCC I 1325

ATCC 15834

ICPB TR2

ATCC 13335

EU6

NCPPB 16.50

NCPPB 1771

Other organisms

I

Ch 31

0362 group

TT9 group

F/I group

M 2/I group

Cluster 2

'rubi' group
Reference [ $\left.{ }^{14} \mathrm{C}\right] \mathrm{DNA}$

ICPB TTIII B6 ICPB TR7

$\begin{array}{lll}67.5 & 70 \cdot 9 & \text { low }\end{array}$

$\begin{array}{lll}65.7 & 70.5 & \text { low }\end{array}$

$66.4 \quad 69 \cdot 9$

$68 \cdot 2 \quad 69 \cdot 4$

$68 \cdot 9$

$69 \cdot 4$

$70 \cdot I$

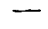

$70 \cdot \mathrm{I}$

$69 \cdot 4$

$67 \cdot 2$

$69 \cdot 9$

$67 \cdot 7$

low

low

low

low

low

low

low

low

-

\section{$-$}

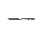

$-$

$-$

$-$

$-$

$-$

$-$

$-$

low

low low

low

$-$

low

low

low

75.9

$75^{\circ} 9$

$76 \cdot 5$

$76 \cdot 2$

$75 \cdot 3$

$75 \cdot 9$

$76 \cdot 6$

$76 \cdot 5$

$76 \cdot \mathrm{I}$

$76 \cdot 4$

75.4

$76 \cdot 2$

$75^{\circ} 9$

$76 \cdot 1$

$75 \cdot 8$

$76 \cdot 1$

$75 \cdot 6$

$7 \mathrm{I} \cdot 8$

$75 \cdot 7$

747

$74^{\cdot} \cdot$

low

low

low

low

low

Thermal stability of intra- and intergroup stable DNA: DNA hybrid

As reference strains for hybridization we selected a representative of each of the three major Agrobacterium groups: Agrobacterium tumefaciens в6 and TTI I I from the groups of the same name in cluster I and A. rhizogenes TR7 from cluster 2 (De Ley, I972; Kersters et al. 1973). In most cases only the stable duplex was allowed to form, by hybridization at $59{ }^{\circ} \mathrm{C}$, followed by denaturing the hybrid. It is apparent (Table I and Fig. 2) that three kinds of stable hybrids are formed, within Agrobacterium. One type is usually almost 
indistinguishable from the homologous duplexes with about 2000 c.p.m. of $\left[{ }^{14} \mathrm{C}\right] \mathrm{DNA}$ duplexed on the filter and a $T_{m(e)}$ of about $75^{\circ} \mathrm{C}$ in $2 \times \mathrm{SSC}$-DMSO. The second type hybridizes less, with about 1000 c.p.m. of duplexed labelled DNA, and has a $T_{m(e)}$ between $67{ }^{\circ} \mathrm{C}$ and $7 \mathrm{I}{ }^{\circ} \mathrm{C}$. The third type is formed in small amounts, about 200 c.p.m. being duplexed; it has no normal denaturation curve. A few examples are given in Fig. 2. Average values are calculated in Table 2 .

The very small 'rubi' group and the individual strains NCPPB I650 and NCPPB I77I hybridize at about $10 \%$ with clusters I and 2, and among themselves (De Ley, 1972; J. De Ley, A. Reynaerts and H. Cattoir, unpublished). The denaturation curve (Table I) of the hybrids is very low.

\section{The nature of the stable heteroduplex}

There are two possible explanations for the low melting point of the heteroduplexes. One is that the molecular hybrid is formed by AT-rich sequences. Alternatively the presence of imperfectly matching base pairs may decrease the stability and $T_{m(e)}$ of heterologous duplexes. Experimental results favour the latter explanation. The hybrid fraction of $\left[{ }^{14} \mathrm{C}\right] \mathrm{DNA}$ from Agrobacterium tumefaciens B2a was prepared on a larger scale by hybridizing first in ten separate flasks, each containing $4 \mu \mathrm{g}$ of labelled DNA, with $48 \mu \mathrm{g}$ of $A$. tumefaciens A6 DNA on a membrane filter, for $16 \mathrm{~h}$ at $59{ }^{\circ} \mathrm{C}$ in $2 \times \mathrm{SSC}$-DMSO. The hybrid fraction of $\left[{ }^{14} \mathrm{C}\right] \mathrm{B} 2 \mathrm{a}$ DNA was then released by denaturing each filter separately for $\mathrm{I} 5 \mathrm{~min}$ at $89{ }^{\circ} \mathrm{C}$ in the same $\mathrm{I} \cdot 2 \mathrm{ml}$ of $2 \times \mathrm{SSC}$-DMSO. A fresh membrane filter with $46 \mu \mathrm{g}$ ordinary denatured B2a-DNA was added to the latter solution and incubated for $\mathrm{I} 6 \mathrm{~h}$ at $59{ }^{\circ} \mathrm{C}$. Similar experiments were carried out with filter-fixed ordinary DNA from Agrobacterium sp. 032 I. The results are shown in Fig. 3. In both cases the duplex of B2a: released $\left[{ }^{14} \mathrm{C}\right] \mathrm{B} 2 \mathrm{a}$ had the same denaturation curve with exactly the same $T_{m(e)}$ as the original total homoduplex. This result excludes the possibility that the heteroduplexes are formed preferentially from AT-rich sequences.

\section{Stability of molecular hybrids formed at $42{ }^{\circ} \mathrm{C}$}

In the cases of low hybridization at $59{ }^{\circ} \mathrm{C}$ or $62{ }^{\circ} \mathrm{C}$ we checked whether the shape of the stability curve would reveal the existence of another, weaker duplex, by hybridizing at a lower temperature. We determined the thermal stability of duplexes after hybridization at $42{ }^{\circ} \mathrm{C}$ between $\left[{ }^{14} \mathrm{C}\right] \mathrm{DNA}$ of Agrobacterium tumefaciens TTI I and filter-fixed DNA of several other strains from different groups (see Table I). In each case there is a similar peak of the labile duplex below $55^{\circ} \mathrm{C}$. No new peaks appeared.

\section{Percentage of DNA relatedness}

Direct hybridization is not the best method for the determination of the percentage DNA relatedness (Hoyer, McCarthy \& Bolton, 1964), and it was not our explicit purpose to measure it. The calculation of a high or moderate percentage DNA relatedness between individual strains relative to a reference strain is not meaningful in direct hybridization because of the high standard deviation of about $20 \%$. For strains with low relatedness (about $15 \%$ or less) the absolute value of the error becomes negligible. Comparisons between group averages are statistically more meaningful. Table 3 shows that the DNA relatedness of the stable duplex between the groups TTI I I and $\mathrm{B} 6$ is about $55 \%$. Between both groups on the one hand and either cluster 2, group TR2, strain 1650 or 177 I on the other hand, the percentage is about I $2 \%$. This figure agrees excellently with results (J. De Ley et al. unpublished) using the initial renaturation rate method (De Ley, Cattoir \& Reynaerts, 1970) where the data are respectively about $50 \%$ and 10 to $15 \%$. With Salmonella typhimurium, Aceto- 


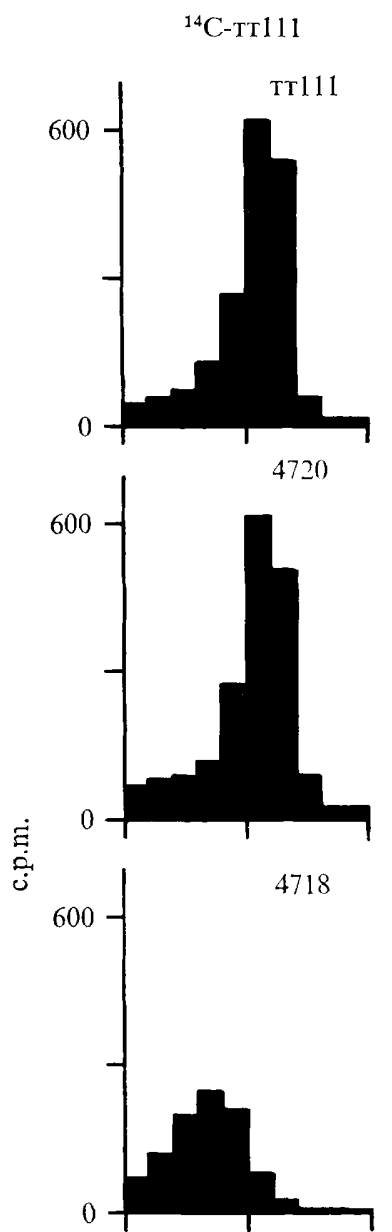

${ }^{14} \mathrm{C}-\mathrm{B} 6$

${ }^{14} \mathrm{C}-\mathrm{TR} 7$
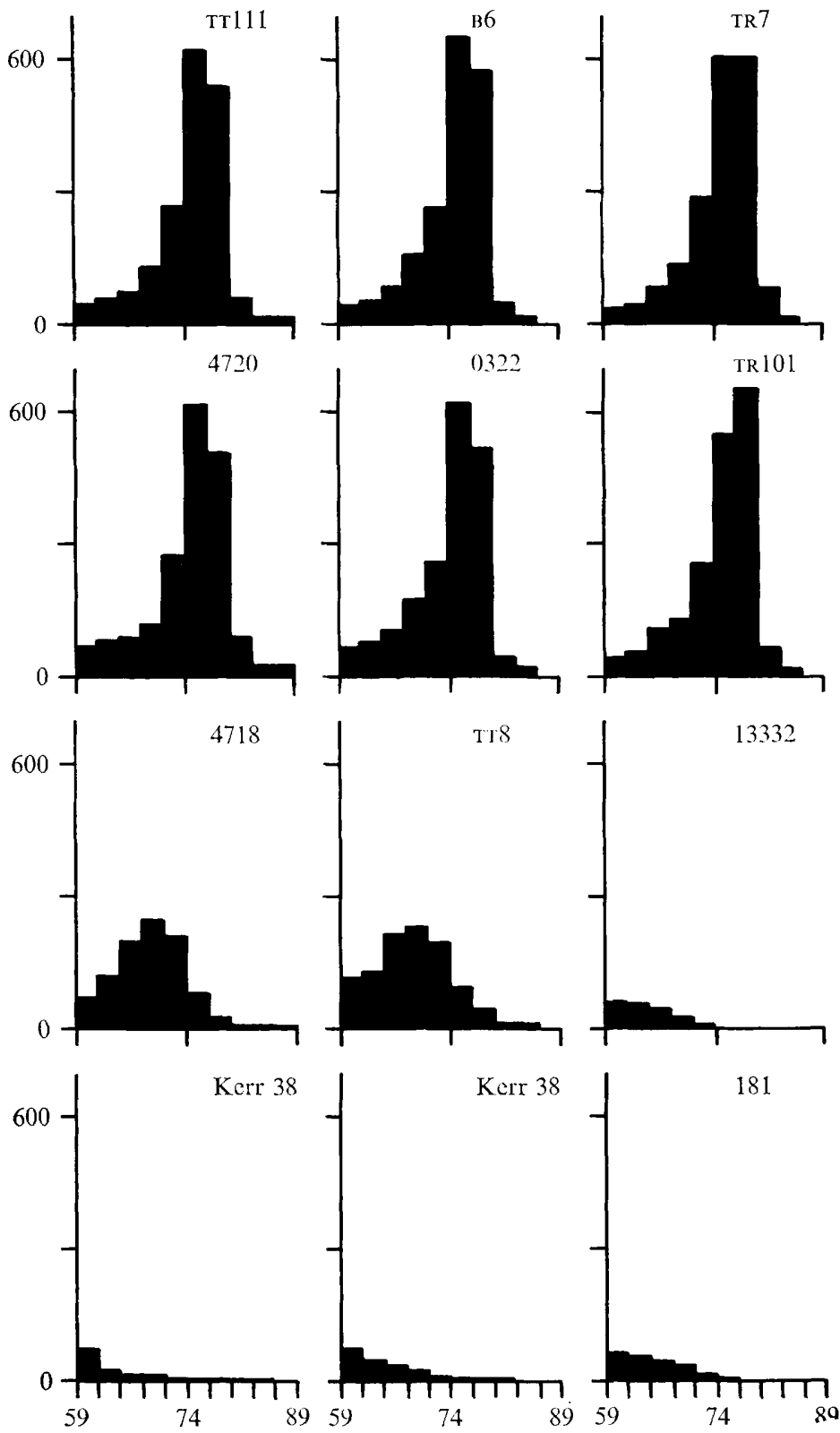

Melting temperature $\left({ }^{\circ} \mathrm{C}\right)$

Fig. 2. Typical differential denaturation curves of Agrobacterium DNA-hybrids. The three columns give examples of hybridizations with $\left[{ }^{14} \mathrm{C}\right] \mathrm{DNA}$ of Agrobacterium tumefaciens TTI I I, B 6 and $A$. rhizogenes TR7, respectively. The top row represents homologous duplexes; the second row, duplexes with strains of the same group; the first and the second curves of the third row are of duplexes between the в 6 and тTI I I groups, all other cases represent different combinations between cluster 2 (TR7) and either the $\mathrm{B} 6$ or TTI I groups. Methods: see text. 
Table 2. Average $T_{m(e)}$ in ${ }^{\circ} \mathrm{C}$ and standard deviation, of the intra- and intergroup stable heterologous DNA hybrids

Cluster or group

TTI I
B6
Cluster 2
RV3
O362
TT9
F/I
M2/I

Reference $\left[{ }^{14} \mathrm{C}\right] \mathrm{DNA}$

\begin{tabular}{ccc} 
TTIII & \multicolumn{1}{c}{ B6 } & TR7 \\
$74 \cdot 6 \pm \mathrm{I} \cdot 4$ & $69 \cdot \mathrm{I} \pm 0 \cdot 6$ & low \\
$69 \cdot 3 \pm 0 \cdot 9$ & $75 \cdot 6 \pm 0 \cdot 4$ & low \\
low & low & $75 \cdot 7 \pm \mathrm{I}$ \\
$68 \cdot 0 \pm \mathrm{I} \cdot 6$ & $7 \mathrm{I} \cdot 6 \pm 0 \cdot \mathrm{I}$ & - \\
$66 \cdot 6 \pm 0 \cdot 9$ & $70 \cdot 7 \pm 0 \cdot 2$ & low \\
$67 \cdot 8 \pm \mathrm{I} \cdot 3$ & $69 \cdot 8 \pm 0 \cdot 4$ & - \\
$67 \cdot 2$ & $69 \cdot 8 \pm 0 \cdot 4$ & - \\
$67 \cdot 6 \pm 0 \cdot 8$ & $69 \cdot 9$ & -
\end{tabular}

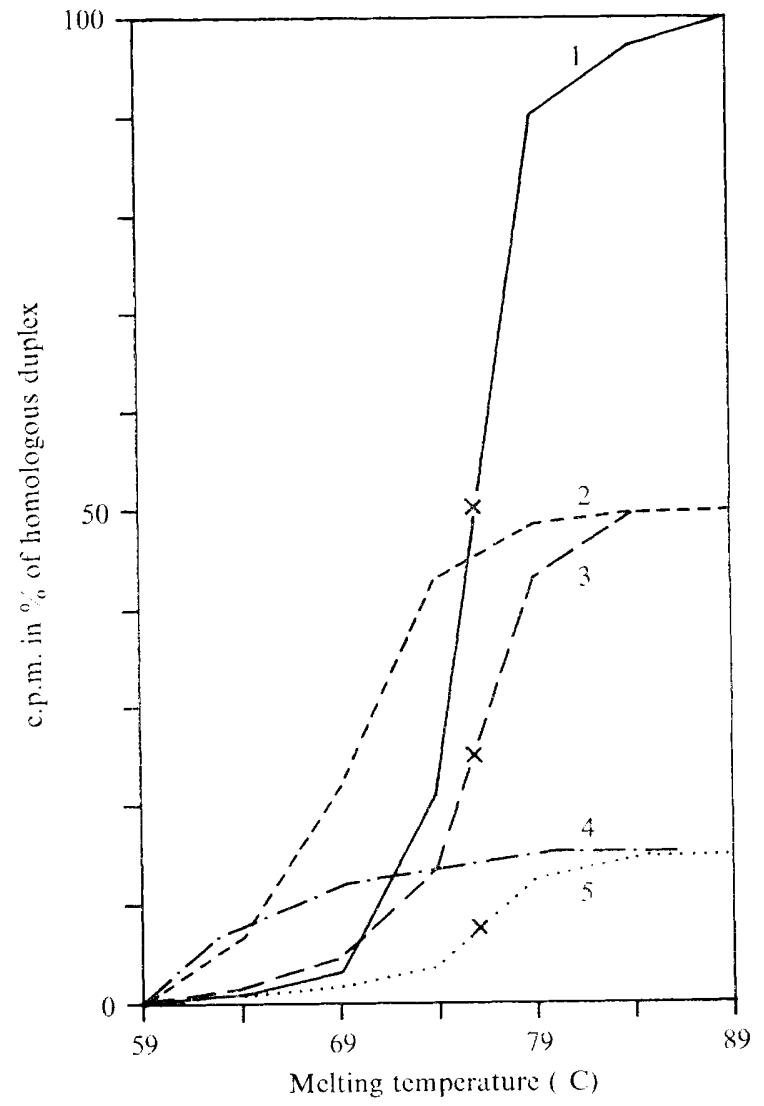

Fig. 3. Denaturation curves of the hybrid fraction after heteroduplexing. Curve 2: the heteroduplex of Agrobacterium tumefaciens $\left[{ }^{14} \mathrm{C}\right] \mathrm{DNA}$ of B2a with A6 DNA. After denaturing at $89{ }^{\circ} \mathrm{C}$ the labelled B2a fraction from this hybrid was collected and hybridized with another filter of native B2a DNA. The latter duplex denatures as shown in curve 3. Curve 4: the heteroduplex of $A$. tumefaciens B2a [14C]DNA with Agrobacterium sp. 032 I. Curve 5: after treatment as above, the duplex of the released $\left[{ }^{14} \mathrm{ClB} 2 \mathrm{a}\right.$ fraction: native $\mathrm{B} 2 \mathrm{a}$. Curve $\mathrm{I}:$ the denaturation curve of the homoduplex $\left[{ }^{14} \mathrm{C}\right] \mathrm{B} 2 \mathrm{a}$ : native B2a as a control. The crosses $(x)$ are the melting points of elution, $T_{m(e)}$. 
Table 3. A semi-quantitative estimate of the degree of DNA relatedness among agrobacteria and two control bacteria, from direct molecular hybridization on membrane filters

The results are expressed in percentages of the average relatedness within each of the three main homologous groups taken as roo ( \pm standard deviation). The standard deviation includes both experimental error and genetic heterogeneity within the group.

\begin{tabular}{|c|c|c|c|}
\hline \multirow[b]{2}{*}{ Bacteria } & \multicolumn{3}{|c|}{ Reference $\left[{ }^{14} \mathrm{C}\right] \mathrm{DNA}$} \\
\hline & TTIII & B6 & TR7 \\
\hline Agrobacterium TTI I I group & $100 \pm 27$ & $58 \pm I 7$ & I3 \\
\hline Agrobacterium в 6 group & $5 \mathrm{I} \pm \mathrm{I} 2$ & $100 \pm 20$ & $12 \pm I$ \\
\hline Agrobacterium cluster 2 & 7 & I I & $100 \pm 2 I$ \\
\hline A. tumefaciens NCPPB I 650 & 一 & - & $15 \pm 3$ \\
\hline A. tumefaciens NCPPB I77I & - & - & II \\
\hline Salmonella typhimurium $\mathrm{I}$ & 3 & - & 13 \\
\hline Acetobacter aceti $\mathrm{ch}_{3 \mathrm{I}}$ & 3 & - & - \\
\hline
\end{tabular}

bacter aceti (Table 3), and many other organisms (J. De Smedt and J. De Ley, unpublished), the relatedness is less than $5 \%$. Whether this indicates some remote phylogenetic ties, or the zero level of the scale, cannot be decided.

\section{DISCUSSION}

The most striking conclusion is the excellent agreement between the present data and the division of the agrobacteria into clusters and groups, on the basis of phenotypic and genotypic criteria (De Ley, 1972; Kersters et al. 1973). The strains with a hybrid- $T_{m(e)}$ around $75{ }^{\circ} \mathrm{C}$ belong in the same group or cluster as the reference strain. Within the groups of cluster I the standard deviation of $T_{m(e)}$ is about I ${ }^{\circ} \mathrm{C}$. Between the groups B6 and TTIII $\Delta T_{m(e)}$ is about $6^{\circ} \mathrm{C}$. Between the small groups Rv3, 0362, TT9, F/I, M2/I, and both large groups, $\Delta T_{m(e)}$ is $4{ }^{\circ} \mathrm{C}$ to $8{ }^{\circ} \mathrm{C}$.

Each of the small groups Rv3, etc., with $T_{m(e)}$ between $67^{\circ} \mathrm{C}$ and $7 \mathrm{I}^{\circ} \mathrm{C}$ (Tables I and 2) are genotypically closer to the $\mathrm{B} 6$ and TTI I groups than to cluster 2 (with TR7). It is very interesting to note, however, that their $T_{m(e)}$ values are always $2{ }^{\circ} \mathrm{C}$ to $4{ }^{\circ} \mathrm{C}$ higher with $\left[{ }^{14} \mathrm{C}\right]$ в6 DNA than with $\left[{ }^{14} \mathrm{C}\right]$ TTI I I DNA. DNA hybridization studies (De Ley, I972; J. De Ley, A. Reynaerts and H. Cattoir, unpublished) showed that each of these five small groups has about half of its chromosomes in common with the others and with the B6 and TTII I groups. The present paper provides some additional information (Tables I and 2); for every strain the stability of the hybrid with $\mathrm{B} 6$ is higher than that with TTI I I. This difference indicates that those five small groups still have a slightly greater relationship with the $\mathrm{B} 6$ group. There is another point of agreement; the RV3 group is phenotypically indistinguishable from the $\mathrm{B} 6$ group (Kersters et al. I973), and its average $T_{m(\theta)}$ value of $7 \mathrm{I} \cdot 6 \pm 0 \cdot \mathrm{I}{ }^{\circ} \mathrm{C}$ is also the highest of those of the five small groups.

There are several possible explanations for the decreased melting point of heteroduplexes. In our case we have shown experimentally that the decrease is not due to duplexes of AT-rich sequences. This possibility is also unlikely on purely theoretical grounds. The average $\Delta T_{m(e)}$ for both types of heteroduplex is $6{ }^{\circ} \mathrm{C}$ and $>13{ }^{\circ} \mathrm{C}$. Assuming that the decrease concerns AT-rich hybrids, their average $\% \mathrm{GC}$ would be 44 and 26 , respectively, since the mean $\% \mathrm{GC}$ of agrobacteria is about 59. From the melting curve of native Agrobacterium DNA we know that the chromosome contains no or not enough fragments with $26 \% \mathrm{GC}$, and not enough with $44 \% \mathrm{GC}$ to explain the hybridization pattern. Brenner \& Cowie 


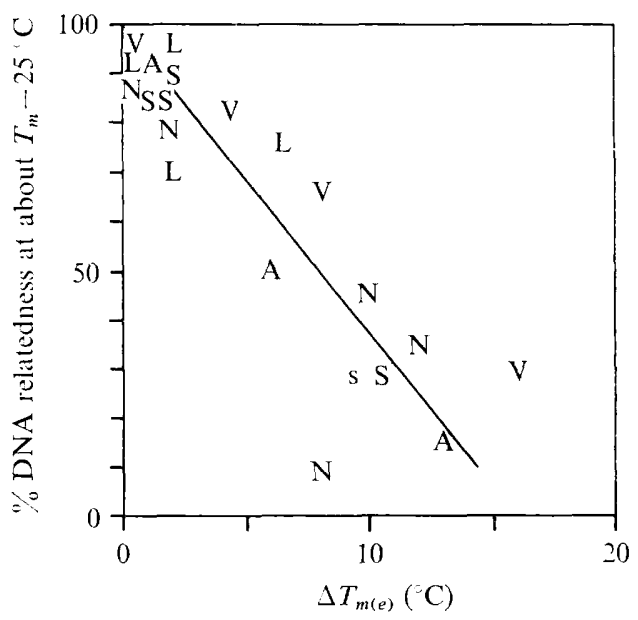

Fig. 4. Relation between the decrease in melting point $\Delta T_{m(e)}$ of heterologous hybrids and the $\%$ DNA relatedness, determined at about $T_{m}-25^{\circ} \mathrm{C}$. Most values are group averages. A, Agrobacterium (this paper); V, Vibrio (Anderson \& Ordal, 1972); s, E. coli KI2 with other coli strains, Alkalescens-Dispar, Shigella, and presumed Citrobacter and Enterobacter (Brenner et al. 1972); L, Leptospira (Haapala et al. 1969); N, Neisseria (Kingsbury et al. 1969); S, E. coli: S. typhimurium (Brenner \& Cowie, 1968).

(I968), in an experiment similar to ours, attempted to explain the low melting point of the DNA hybrid Escherichia coli: Salmonella typhimurium. The $T_{m(e)}$ of the reisolated E. coli: E. coli duplex was far below that of the homologous native duplex; therefore the participation of AT-rich sequences was not convincingly ruled out. In Agrobacterium the situation is quite clear-cut. It is thus most likely that low denaturation curves for the present heterologous hybrids are caused by imperfect base matchings, which results from evolutionary divergence of the clusters and groups of strains.

In the evolution of the agrobacteria, mutational changes also happened in the common parts, frequently to a considerable extent. The less two DNAs hybridize, the less stable is their common part. According to McCarthy \& Farquhar (1972) a change in $1 \%$ of the base pairs decreases $T_{m(e)}$ by about $\mathrm{I} \cdot 6{ }^{\circ} \mathrm{C}$. The total molecular weight of the Agrobacterium genome DNA is $3.7 \times 10^{9}$. DNA relatedness between the $\mathrm{B} 6$, TTI I I and some small groups is about $50 \%$. Single-stranded stretches totalling about $2.8 \times 10^{6}$ bases are still able to hybridize. About $3.75 \%$ or $10^{5}$ of these bases would be mismatched. The duplexing stretches between cluster $\mathrm{I}$ and 2 total about $7 \times 10^{5}$ bases. Because the denaturation curve is flat, $T_{m(e)}$ is difficult to estimate. It is $62{ }^{\circ} \mathrm{C}$ or less. The mis-matching in the common part would be over $8 \%$ or 50000 bases.

The phenomenon of decreased molecular hybrid stability of less related organisms seems to be widespread in bacterial evolution (Fig. 4). It occurs in Neisseria (Kingsbury, Fanning, Johnson \& Brenner, 1969), Leptospira (Haapala, Rogul, Evans \& Alexander, 1969), the Enterobacteriaceae (Brenner \& Cowie, 1968; Brenner, Fanning, Skerman \& Falkow, I972; Brenner, Fanning \& Steigerwalt, 1972), and in Vibrio (Anderson \& Ordal, 1972).

Two more conclusions can be drawn from our data. (i) Since $T_{m(e)}$ of the released hybrid fraction is always the same (Fig. 3), no high or low $\%$ GC fractions remained untouched after evolutionary mutation, and mutations happened all over the genome, even in the common part which may be as small as $15 \%$. (ii) During hybridization the $T_{m(e)}$ of the 
stable homo- or heteroduplex remains unchanged, within experimental error (Fig. I). Thus no high or low $\%$ GC fractions react preferentially.

The nature of the labile duplex below $T_{o R}$ (temperature of optimal renaturation, De Ley et al. I 970) is not known. It is commonly dismissed (e.g. Johnson \& Ordal, 1968) as due to unimportant unspecific bonds, but this is very likely only partially true. In many organisms homologous cistrons different in over $20 \%$ of their base pairs outside the active centre still produce homologous enzymes. However, these cistrons will not hybridize at $T_{o R}$, and they would be dismissed in the unimportant fraction. Undoubtedly quite a number of such cases exist in evolutionarily distant organisms. Our results, as well as a critical examination of published data on the effect of temperature on the hybridization and the stability of hybrids, show that it is frequently unrealistic to hybridize at temperatures of $T_{m}-25^{\circ} \mathrm{C}$ or higher, as advocated by Johnson \& Ordal (1968). De Ley \& Tijtgat (1970) have warned against this procedure because of the uncontrollable release of unlabelled DNA from the filters. In addition, one artificially selects for a stable fraction of the hybrid which may be unrepresentative of the total possible stable duplex, but the less stable fractions, which may be much more important phenotypically, are not detected. The resulting homology has a limited value, particularly for organisms with a homology of less than $70 \%$ at $T_{m}-25{ }^{\circ} \mathrm{C}$. For example, how can one decide without bias what temperature to use for homology measurements between cluster 2 and the в 6 or TTII I group? The results will vary with the temperature and the salt concentration. It seems almost certain that in many cases homology determined at temperatures below $T_{m}-25^{\circ} \mathrm{C}$ is taxonomically more meaningful.

One of us (J.D.L.) is indebted to the Fonds voor Kollektief Fundamenteel Onderzoek for personnel and research grants, and to Mrs J. Rahn-Nalik for correcting the language and style errors.

\section{REFERENCES}

ANDERSON, R. S. \& ORDAL, E. J. (1972). Deoxyribonucleic acid relationships among marine vibrios. Journal of Bacteriology 109, 696-706.

Bray, G. A. (1960). A simple efficient liquid scintillator for counting aqueous solutions in a liquid scintillation counter. Analytical Biochemistry r, 279-285.

Brenner, D. J. \& CowIE, D. B. (I967). Qualitative aspects of microbial DNA duplexes. Carnegie Institution Year Book 66, I06-I I8.

Brenner, D. J. \& CowIE, D. B. (1968). Thermal stability of Escherichia coli-Salmonella typhimurium deoxyribonucleic acid duplexes. Journal of Bacteriology 95, 2258-2262.

Brenner, D. J., Fanning, G. R., Skerman, F. J. \& Falkow, S. (1972). Polynucleotide sequence divergence among strains of Escherichia coli and closely related organisms. Journal of Bacteriology ro9, 953-965.

Brenner, D. J., Fanning, G. R. \& Steigerwalt, A. G. (1972). Deoxyribonucleic acid relatedness among species of Erwinia and between Erwinia species and other Enterobacteria. Journal of Bacteriology r ro, $12-17$.

DE LEY, J. (1972). Agrobacterium: intrageneric relationships and evolution. In Proceedings of the Third International Conference on Plant Pathogenic Bacteria, Wageningen, I971, pp. 25I-259. Wageningen, The Netherlands: Pudoc.

De Ley, J., Bernaerts, M., Rassel, A. \& Guilmot, J. (1966). An approach to an improved taxonomy of the genus Agrobacterium. Journal of General Microbiology 43, 7-1 7 .

De Ley, J., Cattoir, H. \& Reynaerts, A. (1970). The quantitative measurement of DNA hybridization from renaturation rates. European Journal of Biochemistry 12, I33-I 42.

DE LEY, J. \& TiJtgAt, R. (I970). Evaluation of membrane filter methods for DNA:DNA hybridization. Antonie van Leeuwenhoek 36, 46I-474.

Haapala, D. K., Rogul, M., Evans, L. B. \& Alexander, A. D. (1969). Deoxyribonucleic acid base composition and homology studies of Leptospira. Journal of Bacteriology 98, $421-428$.

Heberlein, G. T., De Ley, J. \& TiJtgat, R. (1967). Deoxyribonucleic acid homology and taxonomy of Agrobacterium, Rhizobium and Chromobacterium. Journal of Bacteriology 94, I 6-I 24. 
Hoyer, B. H., MCCARTHY, B. J. \& Bolton, E. T. (I964). A molecular approach in the systematics of higher organisms. Science, New York 144, 959-967.

Johnson, J. L. \& ORdal, E. J. (1968). Deoxyribonucleic acid homology in bacterial taxonomy: effect of incubation temperature on reaction specificity. Journal of Bacteriology 95, 893-900.

Kersters, K., De Ley, J., Sneath, P. H. A. \& Sackin, M. (1973). Numerical taxonomic analysis of Agrobacterium. Journal of General Microbiology 78, 227-239.

Kingsbury, D. T., Fanning, G. R., Johnson, K. E. \& Brenner, D. J. (1969). Thermal stability of interspecies Neisseria DNA duplexes. Journal of General Microbiology 55, $20 \mathrm{I}-208$.

Legault-Démare, J., Desseaux, B., Heyman, T., Séror, S. \& Ress, G. F. (1967). Studies on hybrid molecules of nucleic acids. I. DNA-DNA hybrids on nitrocellulose filters. Biochemical and Biophysical Research Communications 28, 550-557.

MCCARThy, B. J. \& FARQuhar, M. N. (1972). The rate of change of DNA in evolution. In Evolution of Genetic Systems. Brookhaven Symposia in Biology 23, pp. 1-41. Edited by H. H. Smith. London: Gordon and Breach.

MARMUR, J. (1961). A procedure for the isolation of deoxyribonucleic acid from micro-organisms. Journal of Molecular Biology 3, 208-218. 